\title{
Floral and Pollen Studies of Fluted Pumpkin (Telfairia occidentalis Hook. F)
}

\author{
*Adeleke, Martina T. V. ${ }^{1} \quad$ Kazeem, Rhasheedat \\ 1.Department of Plant Science and Biotechnology, Rivers State University, Nkpolu, Port Harcourt, Nigeria
}

\begin{abstract}
The objective of this study is to investigate the occurrence of poor fruit set in Telfairia occidentalis, despite the prolific production of flowers in this plant. Consequently, the floral morphology of the male and female plants with respect to: pollen viability, pollen size count and pollen size distribution for aneuploids and polyploids were examined. Floral buds from the different (Telfairia occidentalis) plants were collected and the pollen viability was assessed using aceto-carmine stain. Pollen sizes were measured using a micrometer, and counted. Pollen fertility results obtained using the aceto-carmine method shows that pollen fertility in Telfairia occidentalis is very high with a percentage value of $93.6 \%$. Pollen sizes were 60 to $68 \mu \mathrm{m}(54.9 \%), 48$ to $60 \mu \mathrm{m}(25.48 \%)$ and 68 to $80 \mathrm{um}(17.64 \%)$. The relatively wide range of pollen size confirms the presence of aneuploids and unreduced microspores, as pollen grain size is proportional to chromosome number. The development of polyploidy among the land races of fluted pumpkin in Nigeria is thus confirmed.
\end{abstract}

Keywords: Pollen grains, aneuploids, pollen viability, polyploidy, Telfairia occidentalis.

DOI: $10.7176 / \mathrm{JBAH} / 11-22-03$

Publication date: November $30^{\text {th }} 2021$

\section{Introduction}

Flowering represents a critical stage in the life cycle of plants, and pollen viability is crucial for efficient sexual reproduction. Viable or fertile pollen is one in which after landing on the stigma of the same or other plants of the same variety or species, under normal conditions, produces a pollen tube and finally discharges its male gametes in the embryo sac, effecting fertilization. According to Rigamoto and Tyagi, (2002) pollen fertility, which can be determined using pollen viability tests in-vitro, is very important in fruit and seed production in flowering plants. Therefore, the knowledge of pollen fertility for any plant species is essential for plant breeders and commercial growers.

Telfairia occidentalis (Fluted pumpkin) is a leafy vegetable of great economic importance. It belongs to the Family Cucurbitaceae and originates from tropical West Africa (Schippers, 2002). It is an herbaceous perennial crop, although it is cultivated as an annual crop especially under the traditional farming system in West Africa. Fluted pumpkin has a vigorous perennial vine growing up to $10 \mathrm{~m}$ or more in length under favourable conditions (Odiaka et al., 2008). It produces tendrils that support the vine. Fluted pumpkin is dioecious with male and female flowers borne on different plants (Okoli and Mgbeogwu, 1983; Purseqlove, 1997). Male plants start flowering earlier (129 days compared with 150 days after planting for female plants) and over a longer period (59 days) versus 17 days for females plant (Akoroda and Adejoro, 1990). About $10-15 \%$ of given female population do not flower in the first year of planting and abortion of fruit is high (Fayeun et al., 2016). Cross pollination in fluted pumpkin is undertaken by insects.

There are more than 800 open male flowers to a single opened female flower. Male flowers open and shed pollen at night, followed by an apparently inefficient insect transfer of pollen to receptive stigmas by midday (Akoroda et al., 1990). Only the male flowers have nectar and pollen, and this may explain infrequent female flower visitation (Okoli and Mgbeogu, 1983). Although a female plant could produce five open flowers, only two or three set fruit, and just one or two are retained and develop fully. Hence, fruit set in Telfaria is generally known to be quite low compared to the large number of flowers produced (especially male ones) in this genus. A number of reasons could be responsible for this, and includes: pollinators, floral morphology, pollen fertility and polyploidy. Cytological studies have shown incidence of aneuploidy and polyploidy in the Cucurbitaceae family in general, and in Telfairia occidentalis in particular (Uguru and Onovo, 2011; Bibi and Okoli, 2014). This study, therefore seeks to investigate the morphology of male and female flowers of Telfairia occidentalis with regard to the ease of pollination, the pollen fertility test and distribution in pollen sizes to ascertain the incidence of aneuploids and unreduced gametes.

\section{Materials and method}

Male and female flowers of a landrace of Telfairia occidentalis in southern Nigeria were collected and their morphology examined and pictures and drawings were made. Pollen grains were removed unto slides, stained with acetocarmine, and examined under the microscope. Counts were made per microscopic field (10) from 2 random samples under a Leitz Diaplan binocular light microscope (x125 magnification). Pollens were analyzed for viability within one hour of collection. Only completely rounded and deeply stained grains were considered 
as viable. Percentage pollen fertility was calculated from the counts made.

The diameter of viable pollen grains was measured with the aid of a graduated eyepiece, and counts were made of the different sizes observed. Giant pollen grains, also considered as $2 \mathrm{n}$ pollen, normally have 1.25 times the diameter of haploid or "n" pollen (Darlington, 1937).

\section{Results and Discussion}

Telfairia occidentalis was observed to be dioecious, with two types of imperfect flowers (staminate and pistilate) borne on different plants (Fig. 1 and 2).

\section{Morphology of the Male Flower}

The male flowers are arranged on a simple pedunculate raceme inflorescence. The flower is polysepalous, with five sepals which are green. The five petals are deeply lobed, elaborate and white in colour to light purple towards their base. The anthers open longitudinally (Fig. 1B). The pollen grains are whitish and sticky. The nectar is found at the base of the stamens (Fig 1C). Only the male flowers have nectar.
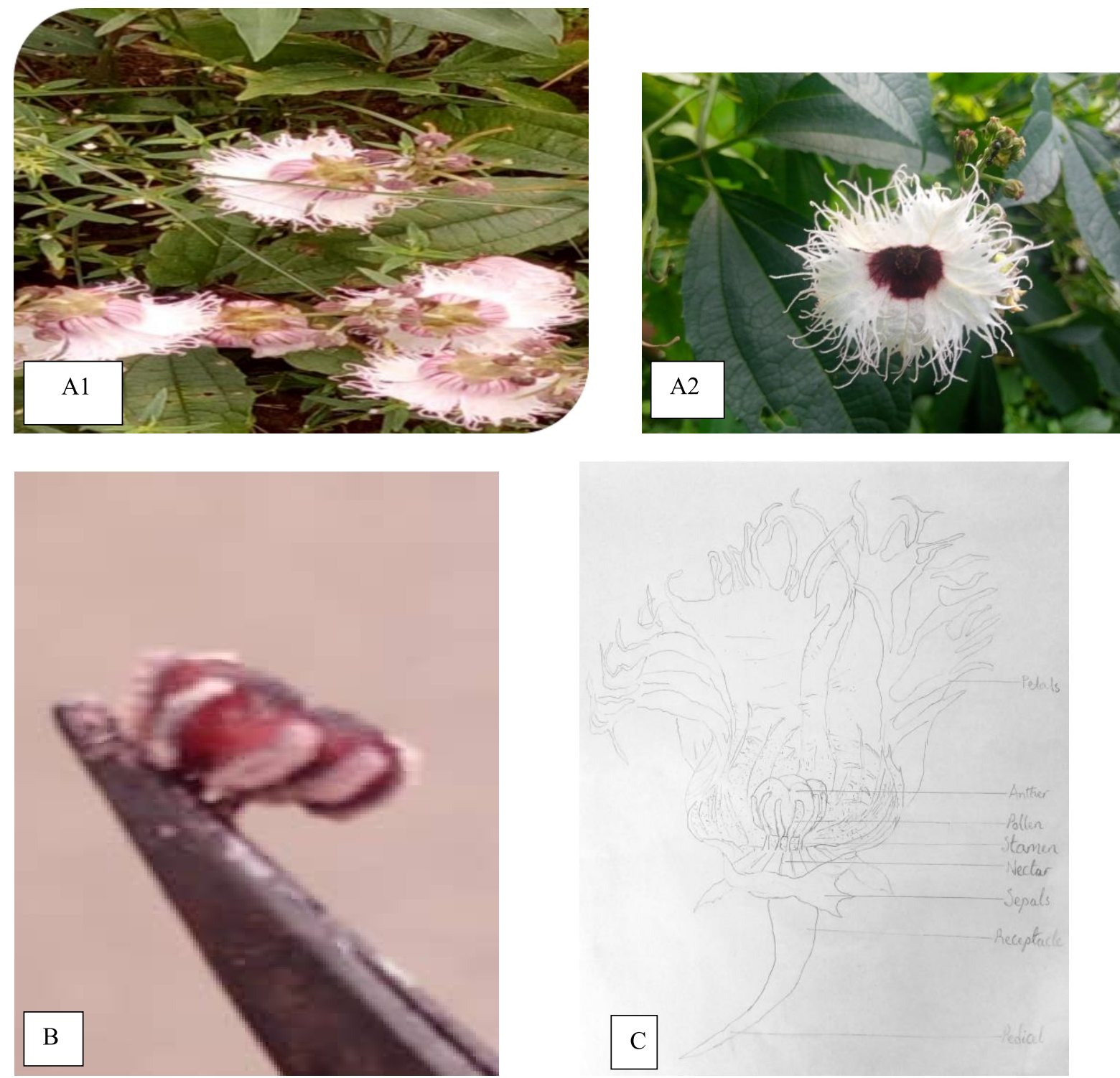

Figure 1: A1 \& A2. Male flowers of Telfairia occidentalis.

B. Anthers of Telfairia occidentalis (suspended on forceps) with sticky whitish pollen.

C. Labeled diagram of the longitudinal section of male flower of Telfairia occidentalis

\section{Morphology of the Female Flower}

The female flowers are always solitary in leaf axils with pedicel from $1.5 \mathrm{~cm}$ to $8.20 \mathrm{~cm}$ in length. The sepals and petals of Telfairia are similar to those found males, except that the female sepals are deciduous and the petals are 
larger (Fig. 2). The color of the stigma is cream. The female flower is syncarpous with three joint stigmas on the inserted style. The ovary is inferior (Fig. 2C).
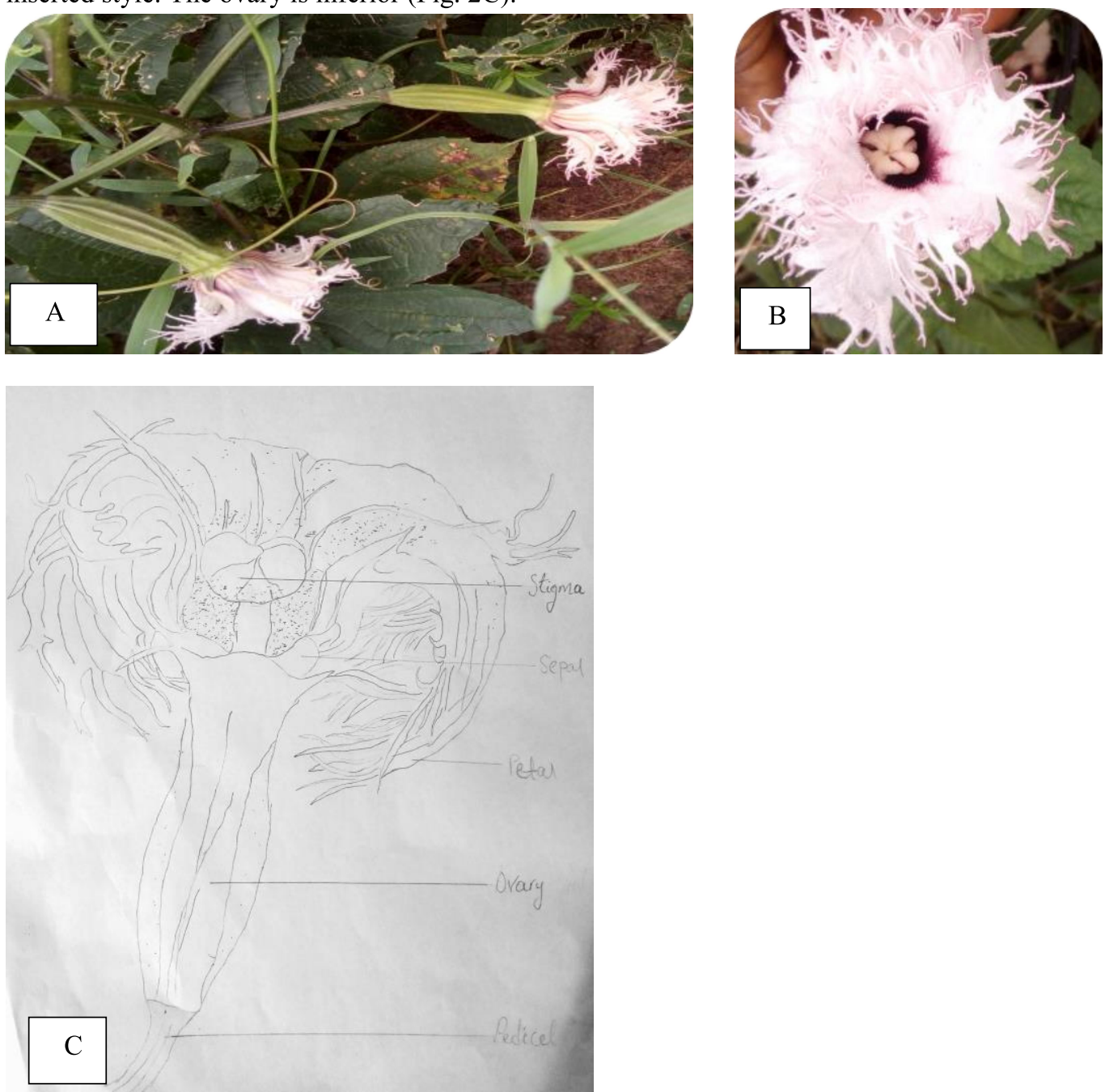

Figure 2. A. Female flower of Telfairia occidentalis.

B. Female flower of Telfairia occidentalis showing the creamy stigma.

C. Labeled diagram of the longitudinal section of female flower of Telfairia occidentalis

\section{Pollen viability, size and distribution}

Pollen fertility in Telfairia occidentalis is very high with an average percentage of $93.6 \%$. Pollen grains of Telfairia occidentalis were also observed to be of different sizes in a normal distribution pattern. The most numerous grain size bracket was 64 to $68 \mu \mathrm{m}$, followed closely by 60 to $64 \mu \mathrm{m}$ (Fig. 3) 


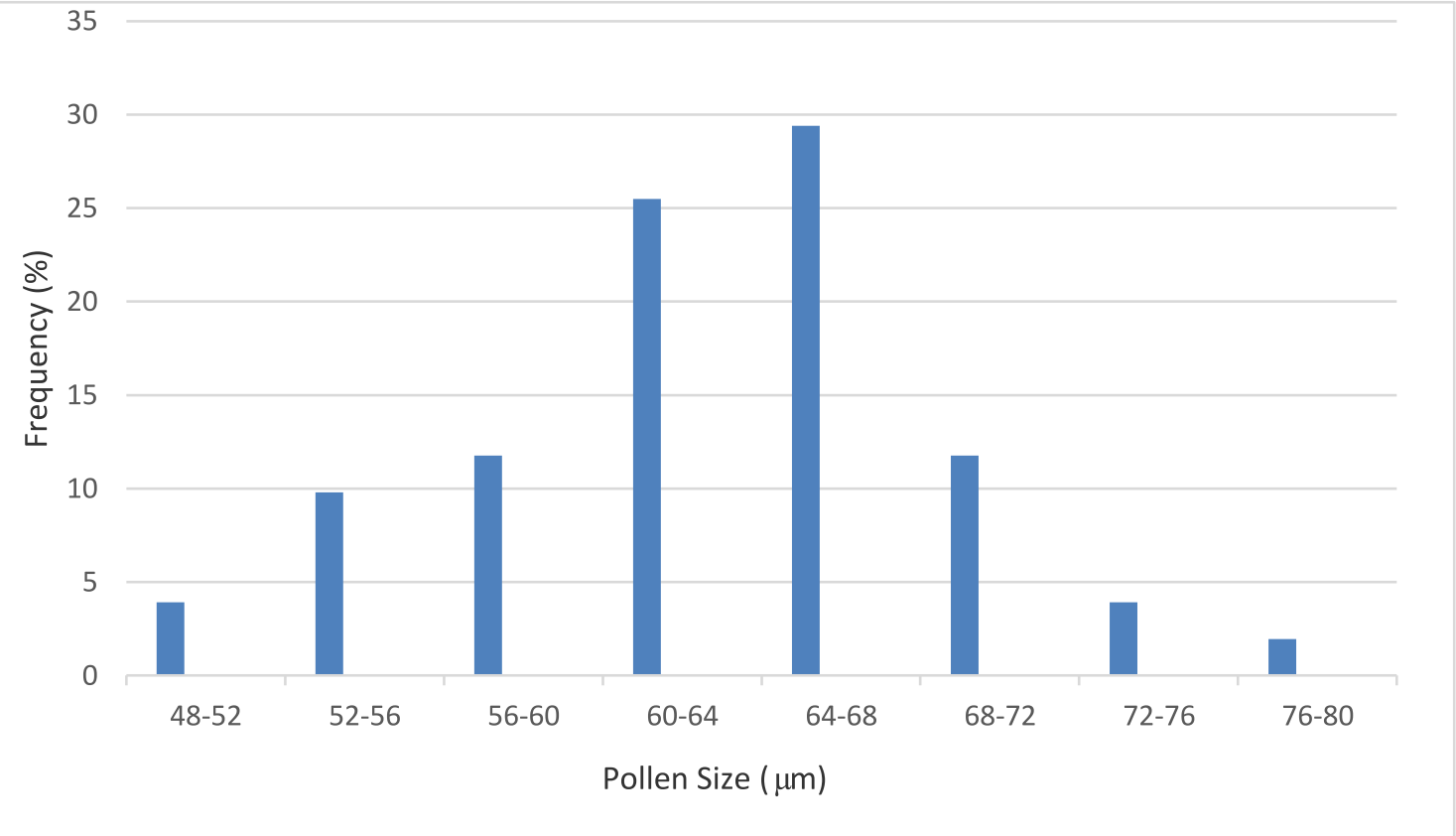

Fig 3. Frequency distribution of pollen diameter in Telfairia occidentalis

The floral parts of the female flower are morphologically just as accessible to pollinators as those of the male, except that pollen and nectar are found only on the male flowers; and these obviously attracts the insect pollinators to them.

The results obtained from the present study confirms that pollen fertility is generally high in this genus. Viability may however depend on the conditions to which the pollen grains were exposed prior to the test, the pollen age and receptivity of the stigma (Dafni et al. 2005). Pollen stainability, which was used as measure of viability, was observed across the range of pollen sizes from $48 \mu \mathrm{m}$ to $80 \mu \mathrm{m}$. Pollen sizes are known to range in angiosperms from 15-200 $\mu \mathrm{m}$. Furthermore, some level of ploidy is known to exist in the Family Cucurbitaceae, and in Telfairia occidentalis in particular (Bibi and Okoli, 2014; Uguru and Onovo, 2011). The observation of different sizes of pollen in this study confirms this, as Chin (1946) in his work on the cytology of polyploid Sorghum, stated that pollen grain size is proportional to chromosome number.

In their mitotic studies of Telfairia occidentalis, Uguru and Onovo's (2011) result revealed 84\% diploids $(2 n=22)$, others were $4 \%$ aneuploids $(2 n=22+1), 1.2 \%$ triploids and $1.2 \%$ tetraploids. In this study, the normal sized pollen which is assumed to be the one that is most numerous as a result of normal meiosis, falls within the range 60 to $64 \mu \mathrm{m}$ and 64 to $68 \mu \mathrm{m}$ (Fig. 3) - the two largest pollen size brackets, representing approximately $55 \%$ of the pollen grains measured. Okoli (1988) reported a range of 58 to $75 \mu \mathrm{m}$ (mean $=65 \pm 4 \mu \mathrm{m}$ ) in Telfairia pollen diameter. The pollen sizes ranging from $48 \mu \mathrm{m}$ to less than $60 \mu \mathrm{m}$ were $25.48 \%$. These could be considered as aneuploids missing a few chromosomes, since pollen grain size is said to be proportional to chromosome size (Chin, 1946); while the larger ones from 68 to 80um were $17.64 \%$. This last category are either aneuploids having additional few chromosomes or unreduced microspores (polyploids).

Polyploids do arise naturally, though many plant species are polyploidized by man through the creation of conditions which disrupt mitosis and meiosis by preventing anaphase separation. Agarwal and Roy (1976) revealed that added advantage of polyploids in Cucurbitaceae is their capacity to propagate vegetatively and a prolonged fruiting season, affecting uniformity of fruits, yield and availability of fruits during the off-season. Polyploidy is an important source of evolution and speciation in plants (Mable, 2004). It can lead to novel gene combinations and expressions which provide the variation on which natural selection can act upon (Darren et al., 2006). In some plant species, polyploids have been associated with the production of larger plant parts (for example, leaves, flowers, fruits and seeds) and specialized characteristics such as seedlessness (Uguru, 1998). Telfairia is grown by farmers mainly for its leaves; so the idea of having polyploids producing larger leaves would be most welcome.

The presence of $25 \%$ well stained (and thus viable) aneuploids in this study could account for poor fruit set in addition to apparent inefficient insect pollination (Akoroda et al., 1990). Furthermore, the physiological perspective of the fruit weight of Telfairia, (between $3-10 \mathrm{~kg}$ ) placing a huge demand on photosynthates from the larger leaves of the female plants (Akoroda et al., 1990) probably explains better why only one or two fruit set are retained and develop fully. Hence, flowering ceases when there were occurences of successful fruits set (Fayeun et al., 2016). 
It can be deduced therefore that in addition to apparent ineffective insect pollination, stigma receptivity and some other factors, pollen fertility does not also necessarily mean pollen viability or successful fertilization with pollination due to aneuploids, hence abortion of fruit is high (Akoroda et al., 1990).

\section{REFERENCES}

Agarwal, P. K. and Roy, R. P. (1976). Natural Polyploids in Cucurbitaceae. Cytogenetical Studies in Triploid Momordica dioica Roxb. Caryologia, 29: 7-13.

Akoroda, MO, and Adejoro, MA (1990). Pattern of vegetative and sexual development of Telfairia occidentalis Hook. F Trop Agric. 67(3): 243-247.

Akoroda, M. O., Ogbechie-Odiaka, N. I., Adebayo, M. L., Ugwo, O.E. and Fuwa, B. (1990) Flowering, pollination and fruiting in fluted pumpkin (Telfairia occidentalis ). Scientia Horticulturae, 43: 197-206. Elsevier Science Publishers B.V., Amsterdam.

Bibi, J. O. and Okoli, B.E. (2014) Morphological, Anatomical and Cytological Studies on Lagenaria breviflora (Benth.) Roberty (Cucurbitacea). Int. J. of Life Sc. 3(3): 131-142.

Chin, T. C. (1946). The Cytology of Polyploid Sorghum. American Journal of Botany, 33(7), 611-614. https://doi.org/10.2307/2437403

Dafni, A., Kevan, P. G. and Husband, B. C. (2005). Practical pollination biology. Enviroquest Ltd, Cambridge, Ontario.

Darlington, C, D. (1937). Recent Advances in Cytology. 2nd edn. London: P. Blakinston's son and Co.

Darren, J. O., Stephen, A. H, Richard, J. A. B. and John, R. P. (2006). Hybridization, Polyploidy and the Evolution of Sexual Systems in Merculiaris (Euphorbiaceae). Evol. 60(9): 1801-1815.

Fayeun, L. S., Odiyi, A. C., Adebisi, A. M., Hammed, L. A. and Ojo, D. K. (2016). Floral Biology of Fluted Pumpkin (Telfairia occidentalis Hook. F.). Not. Sci. Biol., 8(4): 482-488.

Mable, B. K. (2004). 'Why polyploidy is rare in animals than in plants': myths and mechanisms. Biol. J. Linnean Soc., 82(4): 453-466.

Odiaka, N. I., Akoroda M. O. and Odiaka E. C. (2008). Diversity and production methods of fluted pumpkin (Telfairia occidentalis Hook F.). African Journal of Biotechnology 7(8): 944-954.

Okoli, B.E. and Mgbeogu, C. M. (1983). Fluted pumpkin, Telfairia occidentalis: West African vegetable crop. Econ. Bot., 37: 145-149.

Okoli, B. E., Nyananyo, B. L. (1988) Palynology of Telfairia L. (Cucurbitaceae). Folia geobot. phytotax. 23: 281-283. https://doi.org/10.1007/BF02854822

Purseglove, J. W. (1977). Tropical crops dicotyledons. Vol. 1 and 2 combined, 156-159.

Rigamoto, R. R. and Tyagi A.P. (2002). Pollen fertility status in coastal plant species of Rotuma Island. South Pacific Journal of Natural Science 20:30-33.

Schippers, R. R. (2002). African Indigenous vegetables, an overview of the cultivated species. Revised edition on CD-ROM. National Resources International Limited Aylesford, United Kingdom.

Uguru, M. I. (1998). Crop Genetics and Breeding. Ephrata Press, p. 113.

Uguru, M. I. and Onovo, J. C. (2011) Evidence of Polyploidy in Fluted Pumpkin (Telfairia occidentalis Hook F.). African Journal of Plant Science 5(5): 287-290. 